\title{
0601. An inhibitor of pro-inflammatory enzyme soluble epoxide hydrolase improves hippocampus dependent memory function after cardiac arrest and cardio-pulmonary resuscitation in mice
}

\author{
T Fujiyoshi, S Hoka \\ From ESICM LIVES 2014 \\ Barcelona, Spain. 27 September - 1 October 2014
}

\section{Introduction}

Promotion and improvement of cardiopulmonary resuscitation (CPR) technique contributes to increase of the survivors from unexpected cardiac arrest (CA). However, many patients have some neurological deficits, because of few effective treatment to improve the outcome. Hippocampus damage causes a memory dysfunction which suffers the survivors. Microglia activation caused neuron damage following brain stroke and inhibition of proinflammatory soluble epoxide hydrolase $(\mathrm{sEH})$ reduced the infarction size in partial ischemia mice model.

\section{Objectives}

We investigated whether therapeutic inhibition of sEH suppresses neuronal damage and improve memory dysfunction.

\begin{abstract}
Methods
Under isoflurane anesthesia, male adult $\mathrm{C} 57 \mathrm{Bl} / 6$ mice were orally intubated and were connected to the ventilator. A jugular vein catheter, thermometer and electrocardiography (EKG) was placed. CA was induced by potassium chloride injection. When cardiac arrest was confirmed by EKG, isoflurane and mechanical ventilation were disconnected. Brain temperature was maintained at $37.5 \pm 0.5^{\circ} \mathrm{C}$ and rectal temperature is decreased to $28 \pm$ $0.5{ }^{\circ} \mathrm{C}$ during CA. Mechanical ventilation was restarted 30 seconds before CPR and CPR, chest compression and epinephrine administration, was initiated at 8 minutes
\end{abstract}

Kyushu University, Department of Anesthesiology, Fukuoka, Japan after CA onset. The sEH inhibitor 4-phenylchalcone oxide (4-PCO, $5 \mathrm{mg} / \mathrm{kg}$ ip) or vehicle was injected at 5 minutes after CACPR and repeated daily. Neuro-scoring examination was performed 3 days after CAPR. Surviving CA1 hippocampal neurons were counted 1,3 or 10 days and microglia activation was assessed by immunostaining for the activation marker Mac-2 at 1, 3, and 10 days after CACPR Delay fear conditioning was tested 10 days after CA/CPR.RESULTS; Succeeded CPR rate was $86.4 \%$ and $65.9 \%$ of CACPR mice survived for 10 days after CACPR. CACPR mice showed some neurological deficits on day 3 , whereas sham-operated mice showed no deficits. Delayed neuron death appeared on day 3 and persisted 10 days after CACPR in hippocampus CA1 area of CACPR mice. Microglia activated on day 1 , migrated to the ischemia-induced damaged hippocampus area on day 3 and persisted on day 10 in CACPR mice. In CACPR mice, 4-PCO activated microglia on day 3 , but surprisingly, 4-PCO reduced damaged neurons on day 3 , not on day 10. CACPR mice showed reduced freezing to context, not to cued and CACPR mice treated by 4-PCO showed more freezing to context, significantly. This result of fear conditioning test indicated that CACPR caused hippocampus dependent memory deficit, which was improved by $4-\mathrm{PCO}$ treatment.

\section{Conclusions}

Experimental CACPR caused hippocampal neuronal damage, microglial activation, and memory deficit in mice. Inhibition of sEH activated microglia but protected ischemia-induced neurons and improved memory 
function in hippocampus in mice. The inhibition of sEH will be a key of new therapeutic approach to global ischemia-induced damaged brain.

Published: 26 September 2014

doi:10.1186/2197-425X-2-S1-P42

Cite this article as: Fujiyoshi and Hoka: 0601. An inhibitor of proinflammatory enzyme soluble epoxide hydrolase improves

hippocampus dependent memory function after cardiac arrest and cardio-pulmonary resuscitation in mice. Intensive Care Medicine

Experimental 2014 2(Suppl 1):P42.

\section{Submit your manuscript to a SpringerOpen ${ }^{\mathcal{O}}$ journal and benefit from:}

- Convenient online submission

- Rigorous peer review

- Immediate publication on acceptance

- Open access: articles freely available online

- High visibility within the field

- Retaining the copyright to your article

Submit your next manuscript at $\gg$ springeropen.com 